\title{
Clostridiaceae and Enterobacteriaceae as active fermenters in earthworm gut content
}

\author{
Pia K Wüst, Marcus A Horn and Harold L Drake \\ Department of Ecological Microbiology, University of Bayreuth, Bayreuth, Germany
}

\begin{abstract}
The earthworm gut provides ideal in situ conditions for ingested heterotrophic soil bacteria capable of anaerobiosis. High amounts of mucus- and plant-derived saccharides such as glucose are abundant in the earthworm alimentary canal, and high concentrations of molecular hydrogen $\left(\mathrm{H}_{2}\right)$ and organic acids in the alimentary canal are indicative of ongoing fermentations. Thus, the central objective of this study was to resolve potential links between fermentations and active fermenters in gut content of the anecic earthworm Lumbricus terrestris by 16S ribosomal RNA (rRNA)-based stable isotope probing, with $\left[{ }^{13} \mathrm{C}\right]$ glucose as a model substrate. Glucose consumption in anoxic gut content microcosms was rapid and yielded soluble organic compounds (acetate, butyrate, formate, lactate, propionate, succinate and ethanol) and gases (carbon dioxide and $\mathrm{H}_{2}$ ), products indicative of diverse fermentations in the alimentary canal. Clostridiaceae and Enterobacteriaceae were users of glucose-derived carbon. On the basis of the detection of 16S rRNA, active phyla in gut contents included Acidobacteria, Actinobacteria, Bacteroidetes, Chloroflexi, Cyanobacteria, Firmicutes, Gemmatimonadetes, Nitrospirae, Planctomycetes, Proteobacteria, Tenericutes and Verrucomicrobia, taxa common to soils. On the basis of a 16S rRNA gene similarity cutoff of $87.5 \%, 82$ families were detected, 17 of which were novel family-level groups. These findings (a) show the large diversity of soil taxa that might be active during gut passage, (b) show that Clostridiaceae and Enterobacteriaceae (fermentative subsets of these taxa) are selectively stimulated by glucose and might therefore be capable of consuming mucus- and plant-derived saccharides during gut passage and (c) indicate that ingested obligate anaerobes and facultative aerobes from soil can concomitantly metabolize the same source of carbon.
\end{abstract}

The ISME Journal (2011) 5, 92-106; doi:10.1038/ismej.2010.99; published online 8 July 2010

Subject Category: microbe-microbe and microbe-host interactions

Keywords: anaerobic metabolism; gut bacteria; invertebrate microbiology; soil microbiology; 16S rRNA SIP; Lumbricus terrestris

\section{Introduction}

Earthworms can be the major macrofauna of soil and can have profound effects on the structure and fertility of soils (Lee, 1985; Edwards and Bohlen, 1996; Lavelle et al., 1997; Makeschin, 1997). The earthworm gut is oxygen $\left(\mathrm{O}_{2}\right)$ limited and provides ideal in situ conditions for ingested heterotrophic soil bacteria capable of anaerobiosis (Horn et al., 2003; Drake and Horn, 2007). Exoenzymes produced by ingested microorganisms stimulate the degradation of complex organic matter and thus enhance the ability of the worm to assimilate nutrients through a mutualistic digestive system (Brown et al., 2000).

The earthworm alimentary canal contains high amounts of mucus- and plant-derived saccharides

Correspondence: HL Drake, Department of Ecological Microbiology, University of Bayreuth, Dr-Hans-Frisch-Street 1-3, Bayreuth 95445, Germany.

E-Mail: HLD@Uni-Bayreuth.De

Received 1 March 2010; revised 27 April 2010; accepted 28 May 2010; published online 8 July 2010
(Martin et al., 1987; Trigo et al., 1999). Glucosamine, galactosamine, glucose, galactose, mannose and fucose are components of mucopolysaccharides from Lumbricus sp. (Rahemtulla and Lovtrup, 1975) and occur in hydrolyzed alimentary canal contents (Wüst et al., 2009a). The total concentration of monosaccharide equivalents in the aqueous phase of alimentary canal contents can be $>100 \mathrm{mM}$, with many monosaccharides such as glucose approximating $10 \mathrm{mM}$ or more (Horn et al., 2003; Drake and Horn, 2007; Wüst et al., 2009a). The occurrence of such high amounts of saccharides and the anoxia of the worm gut should favor fermentation in situ. Indeed, high concentrations of organic acids and molecular hydrogen $\left(\mathrm{H}_{2}\right)$ occur in the alimentary canal (Horn et al., 2003; Wüst et al., 2009a). For example, over $30 \mathrm{~mm}$ of organic acids (for example, acetate, lactate, succinate, butyrate, propionate and formate) occur in the aqueous phase of the midgut of Lumbricus terrestris (Wüst et al., 2009a), indicating that the midgut harbors a high diversity of fermentative processes and associated taxa, which might include both facultative aerobes and obligate 
anaerobes. Furthermore, living earthworms emit denitrification-derived nitrous oxide $\left(\mathrm{N}_{2} \mathrm{O}\right)$, which can be concomitant to the emission of $\mathrm{H}_{2}$ (Karsten and Drake, 1997; Matthies et al., 1999; Wüst et al., 2009a, b). Although the occurrence of $\mathrm{H}_{2}$ and organic acids is evidence for in situ fermentation, the fermentative microorganisms in the alimentary canal are unknown. Indeed, although diverse bacteria are present in the earthworm gut (Karsten and Drake, 1997; Furlong et al., 2002; Ihssen et al., 2003; Singleton et al., 2003; Horn et al., 2005; Byzov et al., 2009), active bacterial taxa remain unresolved.

On the basis of these collective findings, we hypothesized that diverse obligate anaerobes and facultative aerobes ferment saccharides in the earthworm alimentary canal. The central objective of this study was to resolve potential links between fermentations and active fermenters in gut content of the anecic earthworm L. terrestris by $16 \mathrm{~S}$ ribosomal RNA (rRNA)-based stable isotope probing, with $\left[{ }^{13} \mathrm{C}\right]$ glucose as a model substrate.

\section{Materials and methods}

\section{Earthworms and soil}

Adult L. terrestris L. were purchased from ANZO (Bayreuth, Germany) and maintained in soil at $15^{\circ} \mathrm{C}$ for $\sim 5$ days. Soil was obtained from the meadow Trafo Wiese in Bayreuth (Germany), which is described elsewhere (Horn et al., 2003). Worms had an average weight of $4.2 \pm 0.7 \mathrm{~g}(n=45)$. Gut transit times (Hartenstein et al., 1981) were evaluated to determine whether the fitness and feeding activities of purchased earthworms were similar to that of earthworms collected in the field. In brief, the procedure determines the length of time required for Coomassie Brilliant Blue R-stained soil to pass through the earthworm (Hartenstein et al., 1981). Average gut transit times approximated $11 \mathrm{~h}$, which is similar to that of earthworms collected in the field (Hartenstein and Amico, 1983).

\section{Anoxic gut content microcosms}

Earthworms were washed with sterile water, killed by brief immersion in $70^{\circ} \mathrm{C}$ water and dissected under anoxic conditions in an $\mathrm{O}_{2}$-free chamber (Mecaplex, Grenchen, Switzerland) containing a gas phase of $100 \%$ dinitrogen $\left(\mathrm{N}_{2}\right)$. Midgut and hindgut contents were pooled. A dilution of gut contents was necessary for obtaining adequate samples for chemical and molecular analyses. Gut content was homogenized $(1: 10 \mathrm{w} / \mathrm{v})$ with sterile anoxic sodium phosphate buffer $(\mathrm{pH}$ 7) that contained (in grams per liter) $1.90 \mathrm{NaH}_{2} \mathrm{PO}_{4} \cdot \mathrm{H}_{2} \mathrm{O}$ and $3.36 \mathrm{Na}_{2} \mathrm{HPO}_{4} \cdot 2 \mathrm{H}_{2} \mathrm{O}$. Tubes $(27 \mathrm{ml})$ containing $\sim 8 \mathrm{ml}$ gut homogenates were sealed with rubber stoppers and aluminum caps and flushed with sterile $\mathrm{N}_{2}(100 \%)$. Either $\left[{ }^{12} \mathrm{C}\right]$ glucose or $\left[{ }^{13} \mathrm{C}\right]$ glucose was added from sterile anoxic stock solutions
(100 mM) to a final concentration of $\sim 10 \mathrm{mM}$. Tubes lacking supplemental substrates served as controls. Tubes were incubated upright in the dark at $15^{\circ} \mathrm{C}$. Headspace and liquid phase were sampled with sterile syringes. Samples for nucleic acid extraction were stored at $-80^{\circ} \mathrm{C}$. Values are the mean values of triplicate experiments.

\section{Analytical techniques}

Moisture content was determined by weighing gut content before and after drying at $60^{\circ} \mathrm{C}$ for $72 \mathrm{~h}$. pH was measured with a U457-S7/110 combination $\mathrm{pH}$ electrode (Ingold, Steinbach, Germany). Carbon dioxide $\left(\mathrm{CO}_{2}\right)$ and $\mathrm{H}_{2}$ were measured with a 5890 series II gas chromatograph equipped with a thermal conductivity detector (Hewlett-Packard, Palo Alto, CA, USA; Küsel and Drake, 1995). The concentrations of gases represent the total in both the gas and liquid phases, and are shown per unit volume of the liquid phase (as are the soluble compounds). Soluble organic compounds were analyzed with a 1090 series II high performance liquid chromatograph (Hewlett-Packard; Wüst et al., 2009a).

\section{Nucleic acid extraction}

RNA and DNA were coextracted by bead-beating lysis, organic solvent extraction and precipitation (Griffiths et al., 2000). The purification of RNA from DNA was performed with a Qiagen RNA/DNA mini kit (Qiagen, Hilden, Germany) according to the manufacturer's protocol.

\section{Separation of ${ }^{13} \mathrm{C}$ - and ${ }^{12} \mathrm{C}$-labeled $\mathrm{RNA}$}

A gradient solution (buoyant density $1.785 \mathrm{~g} \mathrm{ml}^{-1}$ ) of cesium trifluoroacetate (buoyant density $2.0 \mathrm{~g} \mathrm{ml}^{-1}$; $83.8 \%$ ), gradient buffer ( $\mathrm{pH} 8 ; 100 \mathrm{mM}$ Tris; $100 \mathrm{mM}$ $\mathrm{KCl} ; 1 \mathrm{mM}$ EDTA; $13.5 \%)$ and formamide $(3.2 \%)$ was added to 500 ng RNA and filled into OptiSeal Tubes (Beckmann, Fullerton, CA, USA). All gradients were set up with the same gradient solution to minimize potential differences that might otherwise occur in the labeling patterns. ${ }^{13} \mathrm{C}$ - and ${ }^{12} \mathrm{C}$-labeled RNA were separated by isopycnic centrifugation $(130000 \times g$ at $20^{\circ} \mathrm{C}$ for $67 \mathrm{~h}$; vertical rotor, VTi 65.2 , Beckmann; Lüders et al., 2004) and fractions $(450 \mu \mathrm{l}$ each) were collected (Figure 1). The densities of the gradient solutions were determined by weighing at $25^{\circ} \mathrm{C}$. RNA was precipitated as described (Degelmann et al., 2009). RNA concentrations were determined using a Quant-iT RiboGreen RNA Assay Kit (Invitrogen, Karlsruhe, Germany) according to the manufacturer's protocol, and RNA was stored at $-80{ }^{\circ} \mathrm{C}$.

\section{Reverse transcription PCR}

Reverse transcription of RNA was performed with random hexamers and Superscript III reverse transcriptase (SuperScript VILO cDNA Synthesis Kit; Invitrogen) according to the manufacturer's protocol. 


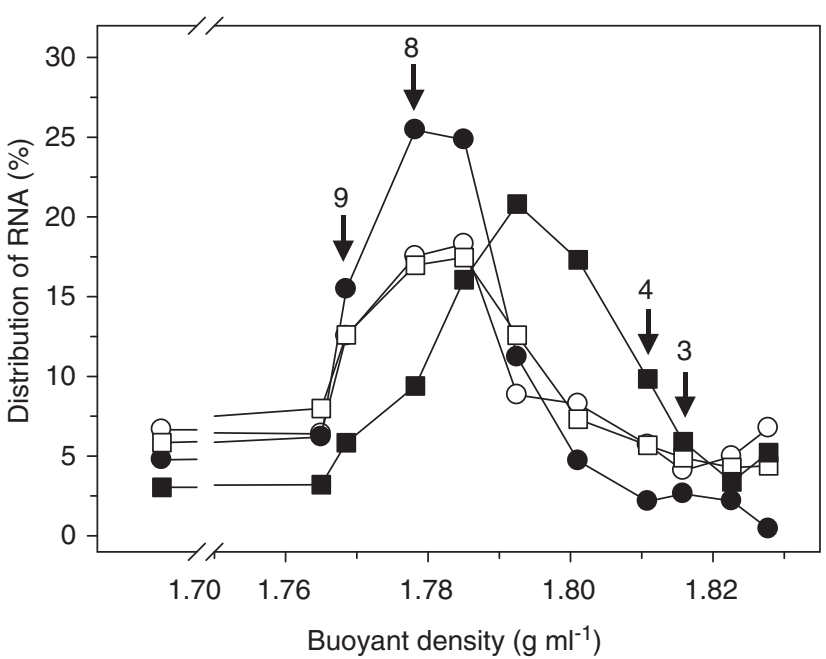

Figure 1 Distribution of RNA in gradient fractions of glucose treatments. Arrows with fraction numbers indicate 'heavy' (3 and 4) and 'light' ( 8 and 9) fractions, which were chosen for further analyses. RNA was measured in all gradient fractions of one replicate. Symbols: empty symbols, RNA extracted at the start of incubation; filled symbols, RNA extracted at $51 \mathrm{~h}$ of incubation; circles, $\left[{ }^{12} \mathrm{C}\right]$ glucose treatment; squares, $\left[{ }^{13} \mathrm{C}\right]$ glucose treatment.

\section{PCR and cloning}

Complementary DNA was amplified by the bacterial $16 \mathrm{~S}$ rRNA gene-specific primer set 27F/907RM (Lane, 1991) using a 5 Prime mastermix (5 Prime, Hamburg, Germany). PCR conditions were as follows: initial denaturation at $95{ }^{\circ} \mathrm{C}$ for $5 \mathrm{~min}, 4$ cycles at $95{ }^{\circ} \mathrm{C}$ for $60 \mathrm{~s}$, at $40^{\circ} \mathrm{C}$ for $60 \mathrm{~s}$ and at $72{ }^{\circ} \mathrm{C}$ for $90 \mathrm{~s}$, and 30 subsequent cycles at $95{ }^{\circ} \mathrm{C}$ for $60 \mathrm{~s}, 50{ }^{\circ} \mathrm{C}$ for $30 \mathrm{~s}$, and $72{ }^{\circ} \mathrm{C}$ for $90 \mathrm{~s}$. The final elongation was at $72{ }^{\circ} \mathrm{C}$ for $5 \mathrm{~min}$. Purified PCR products from fractions three and four that represented labeled RNA ('heavy' fractions; buoyant density $1.809-1.817 \mathrm{~g} \mathrm{ml}^{-1}$ ) were pooled and fractions eight and nine that represented unlabeled RNA ('light' fractions; buoyant density 1.767-1.779 $\mathrm{g} \mathrm{ml}^{-1}$ ) were also pooled (Figure 1). PCR products were ligated into pGEM-T vector plasmids (Promega, Mannheim, Germany), and competent cells of Escherichia coli JM109 were transformed (Promega; protocol as per manufacturer's instructions). Clones with the correct insert were determined with M13 PCR (primer set M13F/M13R) according to published protocol (Messing, 1983) and selected for sequencing at Macrogen (Seoul, South Korea).

\section{Sequence analyses}

Analysis of 16S rRNA complementary DNA sequences $(\sim 880 \mathrm{bp})$ was performed with MEGA (http://www.megasoftware.net; release Beta 4.1.; Tamura et al., 2007) and ARB (http://www. arb-home.de; version 2005; Ludwig et al., 2004). Chimeric sequences were identified by RDP Chimera Check 2.7 (http://rdp8.cme.msu.edu; Cole et al., 2003) and excluded from further analyses. The number of sequences per clone library ranged between 81 and 96. BLASTn 2.2.21 was applied for comparing sequences to those in public databases (Zhang et al., 2000). Sequences were assigned to taxonomic groups using the RDP Classifier with a confidence threshold of $80 \%$ (Wang et al., 2007). Sequences were aligned using the SINA Webaligner (http://www.arb-silva.de) and imported into the latest 16S rRNA gene-based database obtained from the SILVA homepage (Pruesse et al., 2007). Sequences were assigned to a novel family-level group on the basis of a $16 \mathrm{~S}$ rRNA gene similarity $<87.5 \%$ to the next cultivated species (Yarza et al., 2008; Schellenberger et al., 2010). Coverages based on family level were calculated as described (Good, 1958; Schloss et al., 2004). The detected bacterial diversity based on family level was analyzed by rarefaction analysis (Hurlbert, 1971). Phylogenetic trees were calculated using AxML and the neighborjoining method (Saitou and Nei, 1987), which included a bootstrap test with 10000 replicates (Felsenstein, 1985). A taxon was considered to be labeled when its abundance in the clone library from the heavy fractions of the $\left[{ }^{13} \mathrm{C}\right]$ glucose treatment was higher than its abundance in the clone library from the heavy fractions of the $\left[{ }^{12} \mathrm{C}\right]$ glucose treatment.

\section{Nucleotide sequence accession numbers}

The sequences obtained in this study are available from the EMBL nucleotide sequence database under accession numbers FN659069-FN659775.

\section{Results}

Effect of supplemental glucose on fermentation Initial concentrations of glucose approximated $1 \mathrm{mM}$ in unsupplemented anoxic gut content microcosms (Figure 2a). The slight initial increase in glucose concentrations that occurred was indicative of the hydrolysis of polysaccharides in gut contents (Wüst et al., 2009a). The detection of glucose in unsupplemented controls and the detection of cellobiose in all microcosms (Table 1) confirm the occurrence of endogenous saccharides in midgut and hindgut contents (Wüst et al., 2009a). In this regard, as gut contents were diluted 1-10 for the preparation of microcosms (see Materials and methods), the initial concentration of $1 \mathrm{mM}$ glucose in unsupplemented microcosms indicated that the in situ concentration of glucose in gut contents approximated $10 \mathrm{mM}$.

Glucose was completely consumed within $48 \mathrm{~h}$ in glucose-supplemented microcosms and within $24 \mathrm{~h}$ in unsupplemented microcosms. Consumption of supplemental glucose was relatively linear and rapid. Product profiles of $\left[{ }^{12} \mathrm{C}\right]-$ and $\left[{ }^{13} \mathrm{C}\right]$ glucose incubations were nearly identical (Figure 2, Table 1), indicating that microbial activities were similar in both treatments. Approximately $20 \mathrm{mM} \mathrm{CO} \mathrm{CO}_{2}$ and $8 \mathrm{mM} \mathrm{H}_{2}$ accumulated in incubations with supplemental glucose, whereas $\sim 7 \mathrm{mM} \mathrm{CO}_{2}$ and $0.6 \mathrm{mM} \mathrm{H}_{2}$ accumulated in unsupplemented microcosms (Figures $2 \mathrm{~b}$ and $\mathrm{c}$ ), suggesting that supplemental 

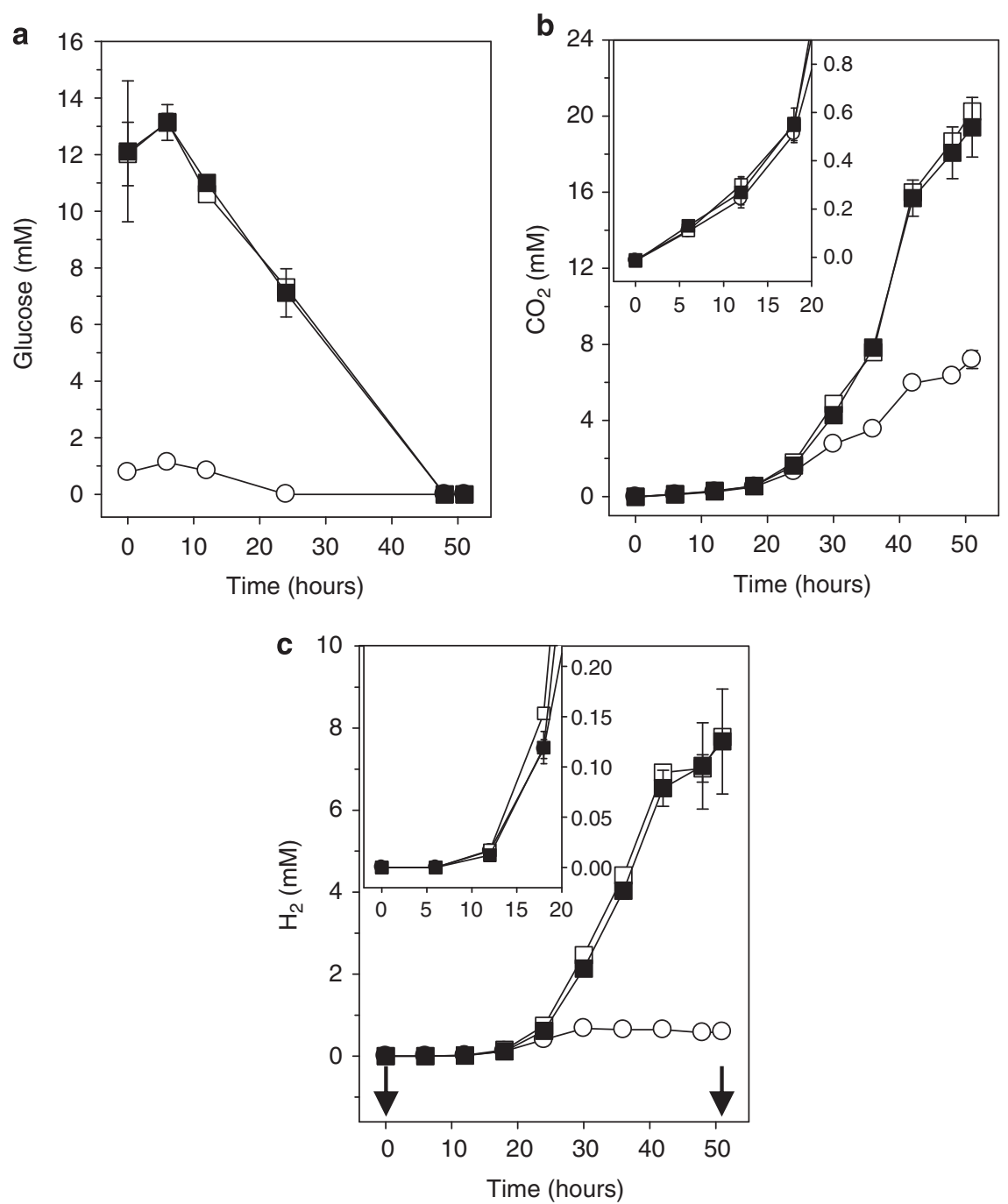

Figure 2 Effect of supplemental glucose (a) on the production of $\mathrm{CO}_{2}(\mathbf{b})$ and $\mathrm{H}_{2}$ (c). The symbols indicate the means of triplicates; error bars indicate s.d.. Arrows indicate the time when samples were taken for RNA stable isotope probing analyses. Insets in (b) and (c) are enlargements of the initial incubation period. Symbols: $\mathbf{\square}$, results from $\left[{ }^{13} \mathrm{C}\right]$ glucose treatment; $\square$, results from $\left[{ }^{12} \mathrm{C}\right]$ glucose treatment; $\bigcirc$, results from unsupplemented control.

glucose decreased the ratios between $\mathrm{CO}_{2}$ and $\mathrm{H}_{2}$ production. However, it cannot be excluded that use of alternative electron acceptors consumed a portion of the $\mathrm{H}_{2}$ formed from either endogenous matter or supplemental glucose. $\mathrm{CO}_{2}$ was produced without apparent delay, whereas the detection of $\mathrm{H}_{2}$ was minimal during the initial incubation period.

All incubations started at a $\mathrm{pH}$ of $\sim 7.3$. $\mathrm{pH}$ values in glucose-supplemented microcosms at $51 \mathrm{~h}$ of incubation were lower than those in unsupplemented microcosms (6.9 and 7.5, respectively), which was consistent with the enhanced production of organic acids (Table 1). Acetate, butyrate, lactate, propionate, succinate and ethanol were end products in glucose-supplemented microcosms. Up to $1 \mathrm{mM}$ of formate was transiently produced in glucose-supplemented microcosms, indicating that formate was an intermediate product during the degradation of glucose. Lactate, formate and succinate occurred as transient products in unsupplemented microcosms, whereas acetate, propionate and ethanol were end products. Acetate was the dominant organic acid detected in all treatments in terms of concentration. Minor concentrations (that is, $<0.06 \mathrm{mM}$ ) of products indicative of amino-acid fermentation (that is, isobutyrate and DL-methylbutyrate; Nanninga and Gottschal, 1985; Gottschalk, 1988) were only detected in unsupplemented incubations (data not shown).

At $51 \mathrm{~h}$ of incubation, $72 \%$ and $60 \%$ of supplemental carbon were recovered in fermentation products of $\left[{ }^{12} \mathrm{C}\right]-$ and $\left[{ }^{13} \mathrm{C}\right]$ glucose incubations, respectively (based on amounts of $\mathrm{CO}_{2}$ and soluble organic compounds detected; Figure2 and Table 1; percentages were calculated after subtracting concentrations in unsupplemented controls). The unrecovered carbon could have been dissimilated to undetected products or assimilated and perhaps 
Table 1 Effect of supplemental glucose on the formation of soluble organic compounds in gut content microcosms ${ }^{\mathrm{a}}$

\begin{tabular}{|c|c|c|c|c|c|c|c|c|c|}
\hline \multirow[t]{2}{*}{ Supplement } & \multirow[t]{2}{*}{ Time (h) } & \multicolumn{8}{|c|}{ Soluble organic compound (mм) } \\
\hline & & Acetate & Lactate & Butyrate & Formate & Succinate & Propionate & Ethanol & Cellobiose \\
\hline \multirow[t]{6}{*}{ None } & 0 & $0.1 \pm 0.0$ & $0.2 \pm 0.0$ & $0 \pm 0$ & $0 \pm 0$ & $0 \pm 0$ & $0 \pm 0$ & $0 \pm 0$ & $0 \pm 0$ \\
\hline & 6 & $0.2 \pm 0.0$ & $0.2 \pm 0.0$ & $0 \pm 0$ & $0 \pm 0$ & $0 \pm 0$ & $0 \pm 0$ & $0 \pm 0$ & $0.1 \pm 0.0$ \\
\hline & 12 & $0.2 \pm 0.0$ & $0.2 \pm 0.0$ & $0 \pm 0$ & $0 \pm 0$ & $0 \pm 0$ & $0 \pm 0$ & $0 \pm 0$ & $0 \pm 0$ \\
\hline & 24 & $1.3 \pm 0.4$ & $0.4 \pm 0.2$ & $0 \pm 0$ & $0.3 \pm 0.1$ & $0.1 \pm 0.0$ & $0 \pm 0$ & $0.5 \pm 0.5$ & $0 \pm 0$ \\
\hline & 48 & $2.6 \pm 0.4$ & $0.1 \pm 0.0$ & $0 \pm 0$ & $0 \pm 0$ & $0.1 \pm 0.0$ & $0 \pm 0$ & $0.3 \pm 0.1$ & $0 \pm 0$ \\
\hline & 51 & $4.0 \pm 0.2$ & $0 \pm 0$ & $0 \pm 0$ & $0 \pm 0$ & $0 \pm 0$ & $0.5 \pm 0.0$ & $0.5 \pm 0.0$ & $0 \pm 0$ \\
\hline \multirow[t]{6}{*}[{}^{12}\mathrm{C}]{ glucose } & 0 & $0.2^{\mathrm{b}}$ & $0.2^{\mathrm{b}}$ & $0^{\mathrm{b}}$ & $0^{\mathrm{b}}$ & $0^{\mathrm{b}}$ & $0^{\mathrm{b}}$ & $0^{\mathrm{b}}$ & $0.2^{\mathrm{b}}$ \\
\hline & 6 & $0.2 \pm 0.0$ & $0.2 \pm 0.0$ & $0 \pm 0$ & $0.1 \pm 0.1$ & $0 \pm 0$ & $0 \pm 0$ & $0 \pm 0$ & $0.2 \pm 0.0$ \\
\hline & 12 & $0.3 \pm 0.1$ & $0.2 \pm 0.0$ & $0 \pm 0$ & $0.1 \pm 0.1$ & $0 \pm 0$ & $0 \pm 0$ & $0 \pm 0$ & $0.1 \pm 0.0$ \\
\hline & 24 & $1.9 \pm 0.2$ & $0.6 \pm 0.2$ & $0 \pm 0$ & $1.0 \pm 0.3$ & $0.1 \pm 0.0$ & $0 \pm 0.1$ & $0.2 \pm 0.4$ & $0.1 \pm 0.0$ \\
\hline & 48 & $5.9 \pm 0.6$ & $3.7 \pm 0.1$ & $1.0 \pm 0.1$ & $0.4 \pm 0.1$ & $0.4 \pm 0.1$ & $0 \pm 0$ & $2.1 \pm 0.1$ & $0 \pm 0$ \\
\hline & 51 & $8.9 \pm 0.4$ & $4.3 \pm 0.0$ & $1.5 \pm 0.1$ & $0 \pm 0$ & $0.6 \pm 0.0$ & $0.5 \pm 0.0$ & $4.2 \pm 1.1$ & $0 \pm 0$ \\
\hline \multirow[t]{6}{*}[{}^{13}\mathrm{C}]{ glucose } & 0 & $0.2^{\mathrm{b}}$ & $0.2^{\mathrm{b}}$ & $0^{\mathrm{b}}$ & $0^{\mathrm{b}}$ & $0^{\mathrm{b}}$ & $0^{\mathrm{b}}$ & $0^{\mathrm{b}}$ & $0.2^{\mathrm{b}}$ \\
\hline & 6 & $0.2 \pm 0.0$ & $0.1 \pm 0.0$ & $0 \pm 0$ & $0 \pm 0$ & $0 \pm 0$ & $0 \pm 0$ & $0 \pm 0$ & $0.1 \pm 0.0$ \\
\hline & 12 & $0.3 \pm 0.0$ & $0.2 \pm 0.0$ & $0 \pm 0$ & $0.1 \pm 0.1$ & $0 \pm 0$ & $0 \pm 0$ & $0 \pm 0$ & $0.1 \pm 0.0$ \\
\hline & 24 & $1.6 \pm 0.4$ & $0.5 \pm 0.2$ & $0 \pm 0$ & $1.1 \pm 0.3$ & $0 \pm 0$ & $0 \pm 0$ & $0.4 \pm 0.2$ & $0.1 \pm 0.0$ \\
\hline & 48 & $5.5 \pm 1.5$ & $3.4 \pm 1.0$ & $0.8 \pm 0.3$ & $0.5 \pm 0.2$ & $0.4 \pm 0.2$ & $0 \pm 0$ & $1.7 \pm 0.6$ & $0 \pm 0$ \\
\hline & 51 & $8.0 \pm 1.9$ & $3.9 \pm 0.8$ & $1.5 \pm 0.6$ & $0.1 \pm 0.1$ & $0.5 \pm 0.2$ & $0.3 \pm 0.0$ & $3.6 \pm 1.0$ & $0 \pm 0$ \\
\hline
\end{tabular}

${ }^{a}$ Unless otherwise stated, values are the means of triplicates ( \pm s.d.).

${ }^{b}$ No s.d. is given because two replicates were analyzed, and the value is the average for the replicates.

converted to intracellular storage polymers. Highest percentages of supplemental ${ }^{12} \mathrm{C}$ - and ${ }^{13} \mathrm{C}$-carbon were recovered in $\mathrm{CO}_{2}$ (19\% and $16 \%$, respectively), lactate $(18 \%$ and $16 \%$, respectively) and acetate (14\% and 9\%, respectively). Approximately $74 \%$ and $63 \%$ of supplemental electrons were recovered in fermentation products of $\left[{ }^{12} \mathrm{C}\right]-$ and $\left[{ }^{13} \mathrm{C}\right]$ glucose incubations, respectively. The highest percentages of electrons derived from supplemental $\left[{ }^{12} \mathrm{C}\right]-$ and $\left[{ }^{13} \mathrm{C}\right]$ glucose were recovered in lactate $(18 \%$ and $15 \%$, respectively), ethanol $(18 \%$ and $15 \%$, respectively) and butyrate (both 17\%).

\section{Active bacteria in gut contents}

A total of 707 16S rRNA complementary DNA sequences were analyzed from 'heavy' and 'light' fractions of $\left[{ }^{12} \mathrm{C}\right]-$ and $\left[{ }^{13} \mathrm{C}\right]$ glucose incubations (Table 2). Family-level coverage approximated 93\% for sequences obtained at the beginning of incubation and $97 \%$ for sequences obtained after $51 \mathrm{~h}$ of incubation. Sequences were assigned to the phyla Proteobacteria (34.5\%), Firmicutes (32.4\%), Actinobacteria (20.9\%), Planctomycetes (4.0\%), Bacteroidetes (3.5\%), Acidobacteria (1.6\%), Verrucomicrobia (1.0\%), Chloroflexi (0.3\%), Gemmatimonadetes $(0.3 \%)$, Nitrospirae $(0.3 \%)$, Tenericutes $(0.1 \%)$ and Cyanobacteria $(0.1 \%)$, or were defined as unclassified Bacteria (0.8\%; Table 2; percentages reflect the relative amount of a given taxon). In total, 82 families were detected, 17 of which were defined as novel family-level groups on the basis of a $16 \mathrm{~S}$ rRNA gene similarity cutoff of $87.5 \%$ (Yarza et al., 2008; Schellenberger et al., 2010).
The rarefaction curve for sequences obtained at the start of incubation was significantly higher than the rarefaction curve for sequences obtained after $51 \mathrm{~h}$ of incubation (Figure 3). This result indicates that a subset of the total taxa was enriched during incubation, thus yielding a lower detected relative bacterial diversity. Sequences obtained at the start of incubation were assigned to 79 families, 17 of which were novel family-level groups, indicating a high and partially unknown diversity of microorganisms in the earthworm gut. Approximately one-third of these 79 families were affiliated with Actinobacteria, a phylum from which diverse family-level taxa have been isolated from soil (Joseph et al., 2003). The detection of 20 families (which included two novel family-level groups) at $51 \mathrm{~h}$ of incubation under anoxic conditions suggests that organisms of these families were capable of anaerobiosis.

\section{Dominant users of glucose-derived carbon}

RNA obtained from $\left[{ }^{13} \mathrm{C}\right]$ glucose treatments became enriched in ${ }^{13} \mathrm{C}$ on the basis of the shift of RNA toward the heavy fractions at the end of the $51 \mathrm{~h}$ incubation, a shift not observed with $\left[{ }^{12} \mathrm{C}\right]$ glucose treatments (Figure 1). Sequences obtained from the 'heavy' fractions of $51 \mathrm{~h}$ samples from $\left[{ }^{13} \mathrm{C}\right]$ glucose treatments were assigned to families Aeromonadaceae, Bacillaceae, Clostridiaceae, Enterobacteriaceae, 'Lachnospiraceae' and 'Peptostreptococcaceae' (Table 2; quotation marks indicate nonvalidated taxa; Euzéby, 2010). Bacillaceae and Clostridiaceae are spore forming, and it is thus noteworthy that gut passage can enhance the germination of spores (Fischer et al., 1997). 
Table 2 Phylogenetic distribution of $16 \mathrm{~S}$ rRNA cDNA sequences obtained from $\left[{ }^{12} \mathrm{C}\right]-$ and $\left[{ }^{13} \mathrm{C}\right]$ glucose treatments ${ }^{\mathrm{a}}$

Phylogenetic affiliation (total relative abundance of phylum)

Phylum

Order, family
Relative abundance of sequences (\%)

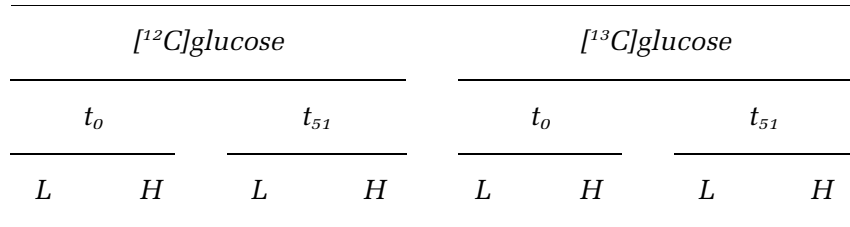

Acidobacteria (1.6)

Actinobacteria (20.9)

Bacteroidetes (3.5)

Chloroflexi (0.3)

Cyanobacteria (0.1)

Firmicutes (32.4)

Gemmatimonadetes (0.3)

Nitrospirae (0.3)

Planctomycetes (4.0)

Proteobacteria (34.5)

Alphaproteobacteria
Acidobacteriales, Acidobacteriaceae

Novel group $4^{\mathrm{b}}$

Novel group $6^{\mathrm{b}}$

Novel group $7^{\mathrm{b}}$

Novel group $8^{\mathrm{b}}$

Novel group $17^{\mathrm{b}}$

Acidimicrobiales,

Acidimicrobiaceae

Iamiaceae

Actinomycetales,

Novel group $5^{\mathrm{b}}$

Actinosynnemataceae

Beutenbergiaceae

Cellulomonadaceae

Cryptosporangiaceae

Frankiaceae

Intrasporangiaceae

Microbacteriaceae

Micrococcaceae

Micromonosporaceae

Mycobacteriaceae

Nakamurellaceae

Nocardiaceae

Nocardioidaceae

Propionibacteriaceae

Pseudonocardiaceae

Sporichthyaceae

Streptomycetaceae

Rubrobacterales,

Novel group $1^{\mathrm{b}}$

Rubrobacteraceae

Solirubrobacterales,

Patulibacteraceae

Flavobacteriales,

Flavobacteriaceae

Sphingobacteriales,

Chitinophagaceae

Flexibacteraceae

Novel group $16^{\mathrm{b}}$

Novel group $14^{\mathrm{b}}$

Family I

Bacillales,

Bacillaceae

Incertae Sedis XII

'Paenibacillaceae'

Clostridiales,

Clostridiaceae

'Lachnospiraceae'

'Peptostreptococcaceae'

Veillonellaceae

Gemmatimonadales,

Gemmatimonadaceae

Nitrospirales,

Nitrospiraceae

Novel group $15^{\mathrm{b}}$

Planctomycetales,

Planctomycetaceae

Caulobacterales, Caulobacteraceae

\begin{tabular}{|c|c|c|c|c|c|c|c|}
\hline 3.7 & 1.1 & - & - & 6.3 & 1.2 & - & - \\
\hline - & - & - & - & 1.0 & 1.2 & - & - \\
\hline 4.9 & 1.1 & - & 1.1 & 2.1 & 1.2 & - & - \\
\hline - & - & - & - & 1.0 & - & - & - \\
\hline - & - & - & - & - & 2.3 & - & - \\
\hline 1.2 & - & - & - & - & - & - & - \\
\hline 1.2 & - & - & - & - & 2.3 & - & - \\
\hline- & - & - & - & 2.1 & 1.2 & - & - \\
\hline- & - & - & - & - & 1.2 & - & - \\
\hline- & 1.1 & - & - & - & - & - & - \\
\hline - & - & - & - & 1.0 & - & - & - \\
\hline 1.2 & 1.1 & - & - & 1.0 & - & - & - \\
\hline- & 1.1 & - & - & 1.0 & - & 1.1 & - \\
\hline - & 2.2 & - & - & - & 1.2 & - & - \\
\hline- & 2.2 & - & - & 1.0 & - & - & - \\
\hline 2.5 & 9.0 & - & - & 5.2 & 4.7 & - & - \\
\hline 1.2 & 1.1 & - & - & - & - & - & - \\
\hline- & 2.2 & - & - & - & 2.3 & 1.1 & - \\
\hline- & 3.4 & - & - & - & 2.3 & - & - \\
\hline - & 2.2 & - & - & 2.1 & 4.7 & - & - \\
\hline 1.2 & 2.2 & - & 1.1 & - & 1.2 & 1.1 & - \\
\hline 6.2 & 4.5 & - & - & 8.3 & 8.1 & - & - \\
\hline- & - & - & - & 2.1 & 1.2 & 1.1 & - \\
\hline 2.5 & 4.5 & - & - & - & 4.7 & - & - \\
\hline 2.5 & 3.4 & - & - & 1.0 & - & - & - \\
\hline 1.2 & - & 一 & - & - & - & 一 & - \\
\hline 2.5 & 5.6 & - & - & 1.0 & 2.3 & - & - \\
\hline 2.5 & 3.4 & - & - & 3.1 & 2.3 & - & - \\
\hline- & - & - & 1.1 & - & 1.2 & - & - \\
\hline 11.1 & 2.2 & - & - & 5.2 & 4.7 & - & - \\
\hline - & - & - & - & - & 1.2 & - & - \\
\hline- & - & - & - & 2.1 & 1.2 & - & - \\
\hline - & - & - & - & 1.0 & - & - & - \\
\hline - & 1.1 & - & - & - & 1.2 & - & - \\
\hline- & - & - & - & - & 1.2 & - & - \\
\hline 1.2 & 1.1 & 6.6 & 5.7 & 1.0 & - & 5.7 & 3. \\
\hline- & 1.1 & - & - & 1.0 & - & - & - \\
\hline - & - & 6.6 & 4.6 & 2.1 & - & 5.7 & - \\
\hline 1.2 & 1.1 & 27.5 & 25.3 & - & - & 9.1 & 50. \\
\hline- & - & 1.1 & 2.3 & - & - & - & 2.2 \\
\hline - & - & 16.5 & 17.2 & 1.0 & - & 51.1 & 4. \\
\hline - & - & - & 1.1 & - & - & - & - \\
\hline - & 1.1 & - & - & 1.0 & - & - & - \\
\hline - & - & - & - & 1.0 & 1.2 & - & - \\
\hline - & - & - & - & 1.0 & - & - & - \\
\hline 7.4 & 7.9 & - & - & 4.2 & 10.5 & 1.1 & - \\
\hline - & - & - & - & 1.0 & - & - & - \\
\hline
\end{tabular}


Table 2 (Continued)

Phylogenetic affiliation (total relative abundance of phylum)

Phylum

Order, family

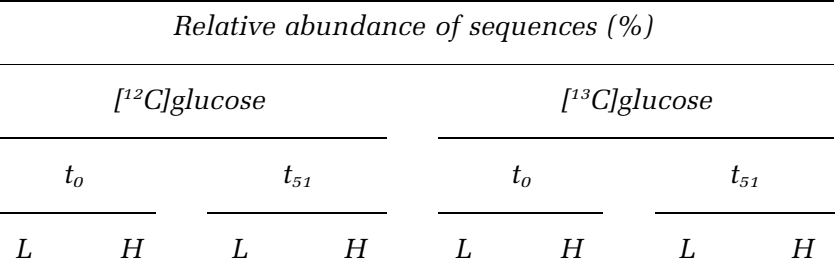

\section{Betaproteobacteria}

Gammaproteobacteria

Deltaproteobacteria

Tenericutes (0.1)

Verrucomicrobia (1.0)

WS3 (0.1)

Unclassified Bacteria (0.8)
Rhizobiales,

Beijerinckiaceae

Bradyrhizobiaceae

Hyphomicrobiaceae

Methylobacteriaceae

Methylocystaceae

Phyllobacteriaceae

Xanthobacteraceae

Rhodobacterales,

Rhodobacteraceae

Rhodospirillales,

Acetobacteraceae

Rhodospirillaceae

Burkholderiales, Alcaligenaceae Incertae sedis 5

Oxalobacteraceae

Aeromonadales,

Aeromonadaceae

Alteromonadales,

Shewanellaceae

Enterobacteriales,

Enterobacteriaceae

Legionellales,

Legionellaceae

Pseudomonadales,

Pseudomonadaceae

Xanthomonadales,

Sinobacteraceae

Xanthomonadaceae

Novel group $9^{\mathrm{b}}$

Novel group $10^{\mathrm{b}}$

Unclassified group $1^{\mathrm{C}}$

Myxococcales,

Cystobacteraceae

Polyangiaceae

Novel group $2^{\text {b }}$

Novel group $3^{\mathrm{b}}$

Unclassified group $2^{\mathrm{d}}$

Unclassified group $3^{\mathrm{e}}$

Opitutales,

Opitutaceae

Verrucomicrobiales,

Novel group $11^{\mathrm{b}}$

Subdivision 3

Incertae sedis

Novel group $12^{\mathrm{b}}$

Novel group $13^{\mathrm{b}}$

\begin{tabular}{|c|c|c|c|c|c|c|c|}
\hline 1.2 & - & - & - & - & - & - & - \\
\hline 4.9 & 3.4 & - & - & 6.3 & 5.8 & 2.3 & - \\
\hline 2.5 & 1.1 & - & - & 4.2 & 2.3 & - & - \\
\hline 1.2 & - & - & - & - & - & - & - \\
\hline 1.2 & 1.1 & - & - & - & - & - & - \\
\hline- & 3.4 & - & - & - & - & - & - \\
\hline 1.2 & 1.1 & - & - & 1.0 & - & - & - \\
\hline 2.5 & 3.4 & - & - & - & - & - & - \\
\hline 1.2 & 2.2 & - & - & - & - & - & - \\
\hline 1.2 & 5.6 & - & - & 4.2 & 4.7 & 1.1 & - \\
\hline- & 1.1 & - & - & - & - & - & - \\
\hline- & - & - & - & 2.1 & 1.2 & - & - \\
\hline- & - & - & - & - & - & 1.1 & - \\
\hline 1.2 & 2.2 & 14.3 & 20.7 & 1.0 & 2.3 & 9.1 & 4.5 \\
\hline- & - & - & - & 1.0 & - & - & - \\
\hline 2.5 & - & 26.4 & 18.4 & 1.0 & - & 9.1 & 34.8 \\
\hline- & - & - & - & - & 1.2 & - & - \\
\hline- & - & - & - & - & 2.3 & - & - \\
\hline- & - & - & - & 2.1 & - & - & - \\
\hline 1.2 & - & - & - & 1.0 & - & - & - \\
\hline 3.7 & 1.1 & - & 1.1 & - & 1.2 & - & - \\
\hline- & 1.1 & - & - & - & - & - & - \\
\hline 6.2 & 1.1 & - & - & 2.1 & 3.5 & - & - \\
\hline- & 1.1 & 1.1 & - & 1.0 & - & - & - \\
\hline 6.2 & - & - & - & 5.2 & 1.2 & - & - \\
\hline- & - & - & - & 1.0 & 2.3 & - & - \\
\hline 2.5 & - & - & - & - & - & - & - \\
\hline- & - & - & - & - & 1.2 & - & - \\
\hline- & 2.2 & - & - & 1.0 & 1.2 & - & - \\
\hline 1.2 & - & - & - & - & - & - & - \\
\hline- & - & - & - & - & 1.2 & - & - \\
\hline- & - & - & - & 1.0 & - & - & - \\
\hline - & - & - & - & 1.0 & - & - & - \\
\hline- & 1.1 & - & - & 1.0 & - & - & - \\
\hline 2.5 & - & - & - & 1.0 & 1.2 & - & - \\
\hline
\end{tabular}

Abbreviations: cDNA, complementary DNA; H, 'heavy' fractions (fractions 3 and 4; Figure 1); L, 'light' fractions (fractions 8 and 9; Figure 1); rRNA, ribosomal RNA; $t_{0}$, at the start of incubation; $t_{51}$, at $51 \mathrm{~h}$ of incubation.

${ }^{a}$ Sequences were assigned to families using the RDP Classifier (Wang et al., 2007) and Blast (Zhang et al., 2000). Number of sequences in the eight clone libraries ranged between 81 and 96 per library. Quotation marks indicate nonvalidated taxa (Euzéby, 2010).

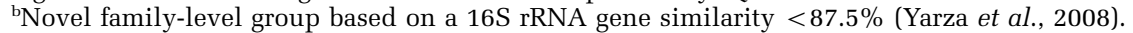

'Next cultivated species: Candidatus 'Entotheonella palauensis' (AF130847; 86.2-90.9\% 16S rRNA gene similarity).

${ }^{\mathrm{d}}$ Next cultivated species: Candidatus 'Lumbricincola sp. Lr-C2' (FM165584; 90.2\% 16S rRNA gene similarity).

'Next cultivated species: Candidatus 'Xiphinematobacter rivesi' (AF217461; 89.5-90.3\% 16S rRNA gene similarity).

In $\left[{ }^{13} \mathrm{C}\right]$ glucose treatments, the relative abundances of sequences affiliated with Clostridiaceae and Enterobacteriaceae were higher in the 'heavy' fractions than in the 'light' fractions, indicating that organisms of these families were dominant users of glucosederived carbon. The closest related cultivated 
species of labeled Clostridiaceae sequences were Clostridium beijerinckii, 'C. chromoreductans', 'C. corinoforum' and $C$. puniceum (Figure 4a). The closest related cultivated species of labeled Enterobacteriaceae-sequences were Buttiauxella spp., Kluyvera cryocrescens, Pantoea agglomerans, Raoultella spp. and Serratia fonticola (Figure 4b). Many closest related species of sequences affiliated with Firmicutes and Gammaproteobacteria have been recovered from soil, water, intestines or feces of animals (Figures $4 \mathrm{a}$ and $\mathrm{b}$ ).

\section{Discussion}

Glucose was conceived in this study to be a model trophic link in the mutualistic digestive system of earthworms (Brown et al., 2000). Glucose is one of the most efficient substrates for the conservation of energy and growth (Reid, 2005). Thus, the high availability of glucose and other saccharides in earthworm gut (Horn et al., 2003; Wüst et al., 2009a) provides ingested soil microbes with a nutritional oasis. The organic acid product profile in glucose-supplemented incubations of gut content (Table 1) was similar to that detected along the alimentary canal (Wüst et al., 2009a) and also to that of high-dilution most probable number of tubes of tryptic soy broth inoculated with earthworm gut contents (Ihssen et al., 2003).

Fermentative processes and general diversity in gut contents

The detection of lactate as a transient intermediate and propionate as an end product in unsupplemented incubations (Table 1) indicates that lactate might

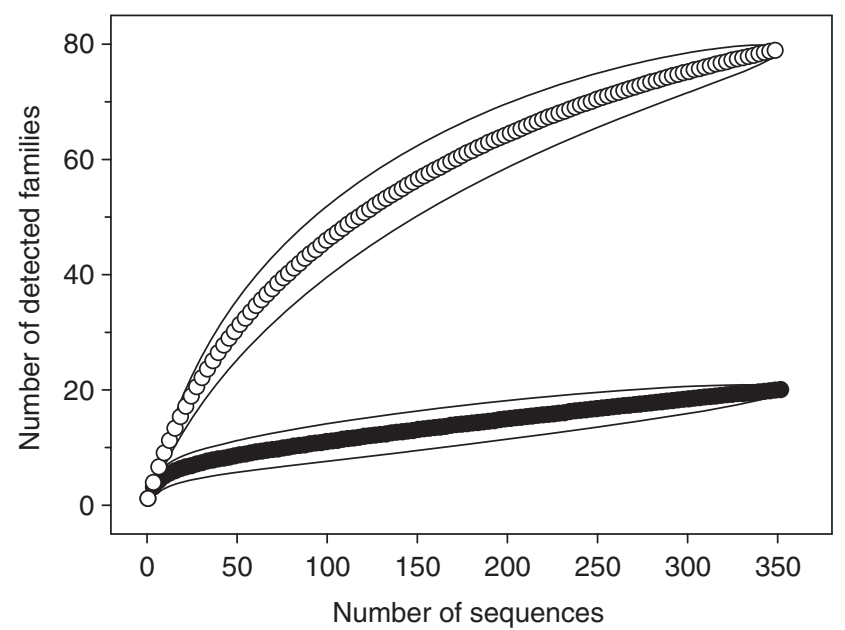

Figure 3 Rarefaction curves of 16S rRNA complementaryDNA sequences were obtained at the start of incubation (empty circles) and after $51 \mathrm{~h}$ of incubation (filled circles). Each curve is based on the total sequences obtained from $\left[{ }^{12} \mathrm{C}\right]$ glucose- and $\left[{ }^{13} \mathrm{C}\right]$ glucosesupplemented incubations. Solid lines enclosing the symbols indicate the $95 \%$ confidence intervals. have been consumed by propionic acid bacteria (Gottschalk, 1988). However, equal amounts of propionate were formed in unsupplemented and glucose-supplemented incubations, suggesting that propionate fermentation was not stimulated by supplemental glucose and that propionate fermenters in the earthworm gut prefer carbon sources other than glucose or lactate. Indeed, sequences related to Propionibacteriaceae were detected before and after incubation of earthworm gut content with $\left[{ }^{13} \mathrm{C}\right]$ glucose, but were not labeled (Table 2), indicating that Propionibacteriaceae-related species did not significantly assimilate carbon from supplemental glucose.

Nearly half of the $\mathrm{CO}_{2}$ produced in glucosesupplemented treatments could be attributed to endogenous sources of carbon (Figure 2b), a result consistent with previous studies showing that gut contents are rich in readily available sources of organic carbon (Brown et al., 2000; Horn et al., 2003; Wüst et al., 2009a). Thus, microorganisms in gut contents consumed endogenous sources of carbon in addition to supplemental glucose. Although most of the organic carbon consumed during fermentation is dissimilated (that is, not assimilated; Gottschalk, 1988), the rapid dissimilation of supplemental glucose was concomitant to the labeling of rRNA, indicating that taxa capable of anaerobiosis in gut contents were poised to respond quickly to increased nutrient availability and assimilated organic carbon.

Active phyla identified by $16 \mathrm{~S}$ rRNA analysis of earthworm gut contents included Acidobacteria, Actinobacteria, Bacteroidetes, Chloroflexi, Cyanobacteria, Firmicutes, Gemmatimonadetes, Nitrospirae, Planctomycetes, (Alpha-, Beta-, Gamma- and Delta-) Proteobacteria, Tenericutes and Verrucomicrobia, taxa common to soils (Table 2). Alpha-, Beta- and GammaProteobacteria, Bacteroidetes, Actinobacteria and Firmicutes are potentially dominant taxa in the earthworm gut, as determined on the basis of $16 \mathrm{~S}$ rRNA gene analyses (Furlong et al., 2002; Singleton et al., 2003; Knapp et al., 2009). Furthermore, species related to Aeromonadaceae, Comamonadaceae, Enterobacteriaceae, Flavobacteriaceae, Moraxellaceae, 'Paenibacillaceae', Pseudomonadaceae, Rhodocyclaceae, Sphingobacteriaceae and Actinobacteria have been isolated from the alimentary canals of earthworms (Ihssen et al., 2003; Horn et al., 2005; Byzov et al., 2009; Knapp et al., 2009). These findings show the diverse taxa that might be metabolically active in the earthworm gut, many of which might participate in polymer hydrolysis in situ (MartinCarnahan and Joseph, 2005; Bernadet and Bowman, 2006; Priest, 2009).

Sequences obtained before incubation were assigned to 14 phyla, whereas sequences obtained after incubation with glucose were assigned to only 4 phyla, with Firmicutes and Proteobacteria being dominant (Table 2). Clostridiaceae and Enterobacteriaceae were the labeled families (Table 2). 
No. of sequences

a

Bacillaceae

Incertae Sedis XII

"Paenibacillaceae"

Clostridiaceae

"Lachnospiraceae"
96 t51_12L80 (FN659473)

"Bacillus arbutinivorans" (AF519469)

soil bacterium (FM956746) t51_13L51 (FN659634) aerosol bacterium (DQ129449)

Bacillus firmus (FJ607055)

83. Bacillus weihenstephanensis (AB021199)

freshwater bacterium (AY345553)

t51_13H1 (FN659686)

62 "Bacillus samanii" (EF036537)

t51_12H87 (FN659563) Bacillus cereus (EF690421)

volcanic deposit bacterium (DQ490404) to_12H16 (FN659160)
99 t51_12H105 (FN659580)

glucose $\left[{ }^{13} \mathrm{C}\right]$ glucose

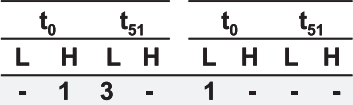

1 (DQ90029) 451 13L62 (FN659644) 20- t51_13L62 (FN659644) Paenibacillus graminis (FJ544322) - goose feces bacterium (FJ390556) $55{ }_{91}{ }^{\mathrm{t}}$ [1_-13L111 (FN659677)

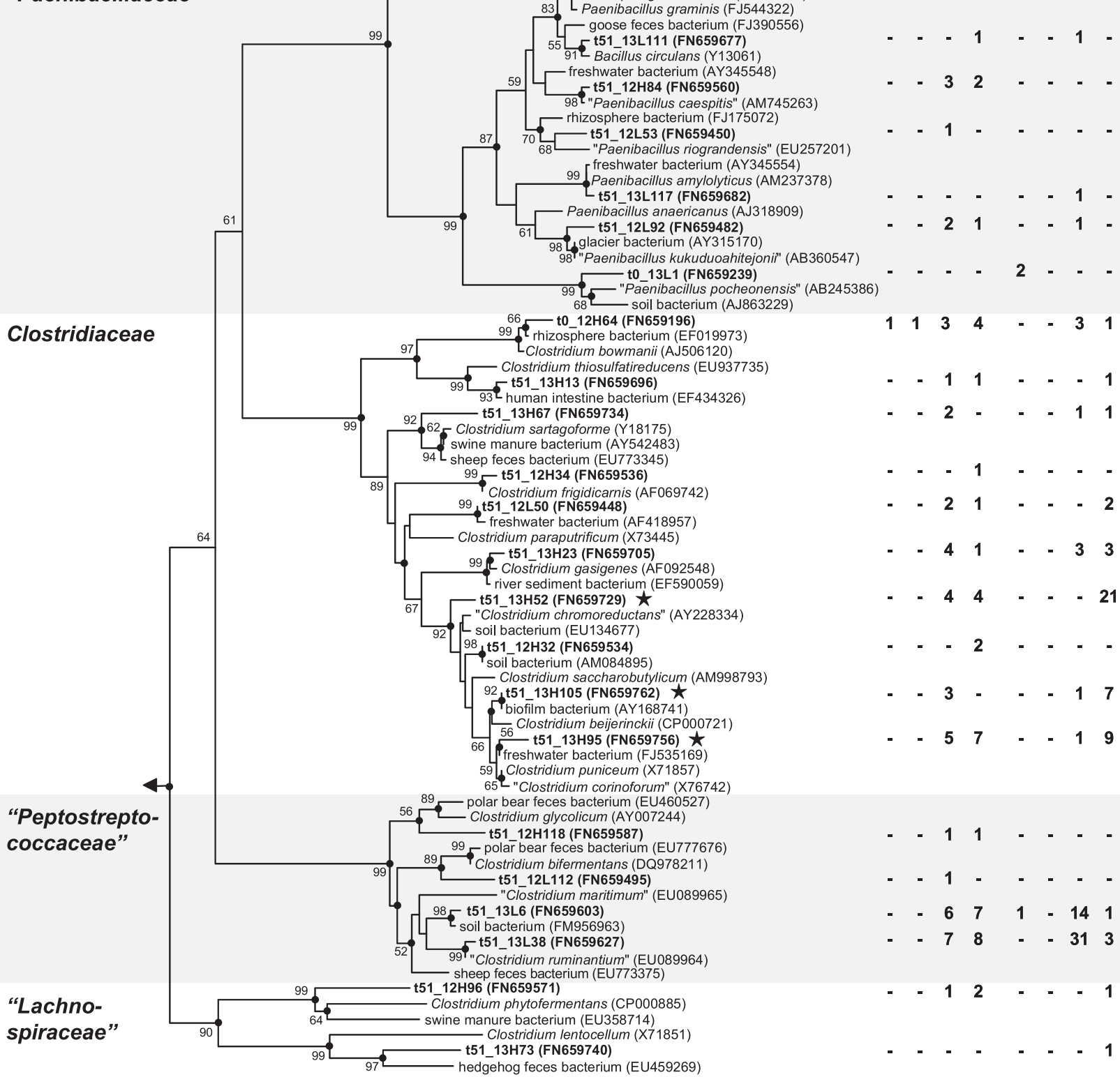


These glucose-assimilating taxa occur in soils (Hamberger et al., 2008; Degelmann et al., 2009; Schellenberger et al., 2010) and have robust metabolic capacities and doubling times that can range between 0.5 and $3 \mathrm{~h}$ (Francis et al., 2000; Wiegel et al., 2006), factors that likely contributed to their competitiveness.

Many fermentative or facultative microorganisms can reduce nitrate or nitrite (Cole, 1990; Umarov, 1990). Active genera included Aeromonas, Bacillus, Buttiauxella, Clostridium, Enterobacter, Flavobacterium, Paenibacillus and Pseudomonas (Table 2, Figures 4a and b), and earthworm gut isolates affiliated with these genera have the ability to reduce either nitrate or nitrite and produce $\mathrm{N}_{2} \mathrm{O}$ (Ihssen et al., 2003). Different regions of the alimentary canal yield different organic acid, $\mathrm{H}_{2}$ and $\mathrm{N}_{2} \mathrm{O}$ signatures (Wüst et al., 2009a), reflecting potential trophic links that might occur between fermentation and denitrification during gut passage (for example, when denitrifiers use fermentation products as a source of reductant).

\section{Clostridiaceae}

Most sequences derived from 'heavy' fractions after $\left[{ }^{13} \mathrm{C}\right]$ glucose incubation were affiliated with the genus Clostridium sensu stricto (Collins et al., 1994; Figure 4a). Species of this genus are considered to be obligate anaerobes and can dissimilate glucose to acetate, butyrate, lactate, ethanol, $\mathrm{H}_{2}$ and $\mathrm{CO}_{2}$ (Rainey et al., 2009). The formation of these products was enhanced by glucose (Figure2 and Table 1). The closest related cultured species of labeled clostridial sequences, $C$. beijerinckii and C. puniceum, can produce substantial amounts of $\mathrm{H}_{2}$ in addition to butyrate, acetate, formate and butanol (Rainey et al., 2009). Although $\mathrm{H}_{2}$ is a trophic link to methanogenesis and acetogenesis (Drake et al., 2006, 2008; Hedderich and Whitman, 2006; Liu and Whitman, 2008; McInerney et al., 2008), methanogens and acetogens are not metabolically significant in the earthworm gut (Karsten and Drake, 1995).

Most electrons derived from supplemental glucose were recovered in lactate, but classic lactate-producing genera such as Lactococcus, Lactobacillus and Streptococcus were not detected, which is not surprising, as most species in these taxa are not considered to be common to soil (Teuber et al., 1992; Hammes and Hertel, 2009; Whiley and Hardie, 2009). Similarly, Lactovum, a lactateforming genus isolated from acidic soil (Matthies et al., 2004; Drake, 2010), was not detected. Lactate can also be produced by saccharolytic clostridia and can be the main fermentation product of these organisms under certain conditions (Wiegel et al., 2006). For example, C. perfringens produces mainly lactate under carbon-rich conditions (Macfarlane and Macfarlane, 2003). Some sequences were closely affiliated with $C$. gasigenes and $C$. frigidicarnis (Figure 4a), species that can grow at low temperatures and secret hydrolytic exoenzymes (Broda et al., 1999, 2000; Akila and Chandra, 2003), indicating that psychrotolerant clostridia might be involved in the degradation of organic matter in the earthworm alimentary canal. 'Peptostreptococcaceae' are closely related to Clostridiaceae (Ludwig et al., 2009 and Figure 4a) and were enriched during incubation (Table2 and Figure 4a). However, the high relative abundance of 'Peptostreptococcaceae' -related sequences in the 'light' fractions of the $\left[{ }^{13} \mathrm{C}\right]$ glucose treatment indicated that 'Peptostreptococcaceae' used endogenous sources of organic carbon.

Enterobacteriaceae

Species of the family Enterobacteriaceae are facultative aerobes having both a respiratory and a fermentative metabolism (Brenner, 1992). Characteristic fermentation products of Enterobacteriaceae include formate, succinate, lactate, acetate, ethanol, $\mathrm{H}_{2}$ and $\mathrm{CO}_{2}$ (Brenner and Farmer, 2005), products consistent with those detected in glucose treatments (Figure2 and Table 1) and also with the apparent fermentation products detected along the earthworm alimentary canal (Wüst et al., 2009a). Most Enterobacteriaceae are able to reduce nitrate to nitrite (Brenner, 1992) and might therefore be at least partly responsible for the low nitrate concentrations in the alimentary canal compared with those of preingested soil (Horn et al., 2003; Wüst et al., 2009a). Several genera within the Enterobacteriaceae (Buttiauxella, Kluyvera, Pantoea, Raoultella and Serratia) were labeled with $\left[{ }^{13} \mathrm{C}\right]$ glucose-derived carbon (Figure 4b). Species of these genera are able

Figure 4 Phylogenetic tree of 16S rRNA complementaryDNA sequences (bold) retrieved from the earthworm gut and reference sequences of the Firmicutes (a) and Gammaproteobacteria (b). Only representative sequences are shown. The values next to the branches represent the percentages of replicate trees $(>50 \%)$ in which the associated taxa clustered together in the bootstrap test $(10000$ replicates). Dots at nodes indicate confirmation of topology by AxML using the same data set. Labeled taxa are marked with stars. Methanosarcina barkeri (AF028692) was used as outgroup. Accession numbers are in parentheses. Quotation marks indicate nonvalidated taxa (Euzéby, 2010). Abbreviations: $\mathrm{t}_{0}$, at the start of incubation; $\mathrm{t}_{51}$, at $51 \mathrm{~h}$ of incubation; $\mathrm{L}$, 'light' fractions; $\mathrm{H}$, 'heavy' fractions. (a): The family Veillonellaceae was excluded because the sequence that affiliated with this family (t51 12H90) was shorter than $700 \mathrm{bp}$. The phylogenetic tree was calculated using the neighbor-joining method $(50 \%$ minimum similarity filter; 651 valid positions between 104 and 815 of the 16S rRNA gene of E. coli). Bar indicates 0.01 estimated change per nucleotide. (b): The labeled sequence t51_13H112 (next cultivated species Serratia fonticola, AY236502, 99\% 16S rRNA gene similarity) was excluded from tree calculation because it was shorter than $700 \mathrm{bp}$. The phylogenetic tree was calculated using the neighbor-joining method (50\% minimum similarity filter; 698 valid positions between 101 and 816 of the $16 \mathrm{~S}$ rRNA gene of E. coli). Bar indicates 0.05 estimated change per nucleotide. 


\section{Enterobacteriaceae}

8 [51_13H30 (FN659711) ᄎ insect gut bacterium (EU344923)

631 Raoultella terrigena (Y17670)

71 Buttiauxella brennerae (AJ233401)

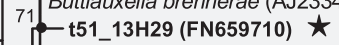

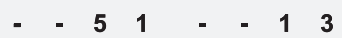

56 Buttiauxella gaviniae (AJ2333403)

60 Buttiauxella agrestis (AJ233400) rhizosphere isolate (AJ252606)

62 t51_13H79 (FN659742) ᄎ

59 insect gut bacterium (DQ068853)

Kluyvera cryocrescens (AM992189)

— t51_13H15 (FN659698) $\star$

- insect gut bacterium (DQ068815)

- Pantoea agglomerans (DQ133596)

76 t51_12L120 (FN659698) ᄎ

soil bacterium (EU307101)

t51_13H61 (FN659730)

human skin bacterium (EU538330)

- Leclercia adecarboxylata (FJ462700)

61151_13L84 (FN659658)

Enterobacter amnigenus (EU438866)

97 soil bacterium (EU567038)

75 t51_12H82 (FN659558)

Citrobacter gillenii (AF025367)

91 chicken intestine bacterium (DQ342333)

biofilm bacterium (FJ165548)

-t51_13H106 (FN659763) $\star$ - $\quad-\quad-\quad-\quad-\quad-12$

Raoultella ornithinolytica (EU834264)

00

$L_{\text {t51_13H82 (FN659744) } \star}$ t51_13L105 (FN659672)

${ }_{99}$ insect gut bacterium (DQ068825)

t51_12L124 (FN659503)

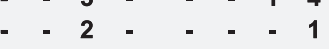

Shewanellaceae

Aeromonadaceae

100 Shewanella baltica (CP000891)

human skin bacterium (EU539070)

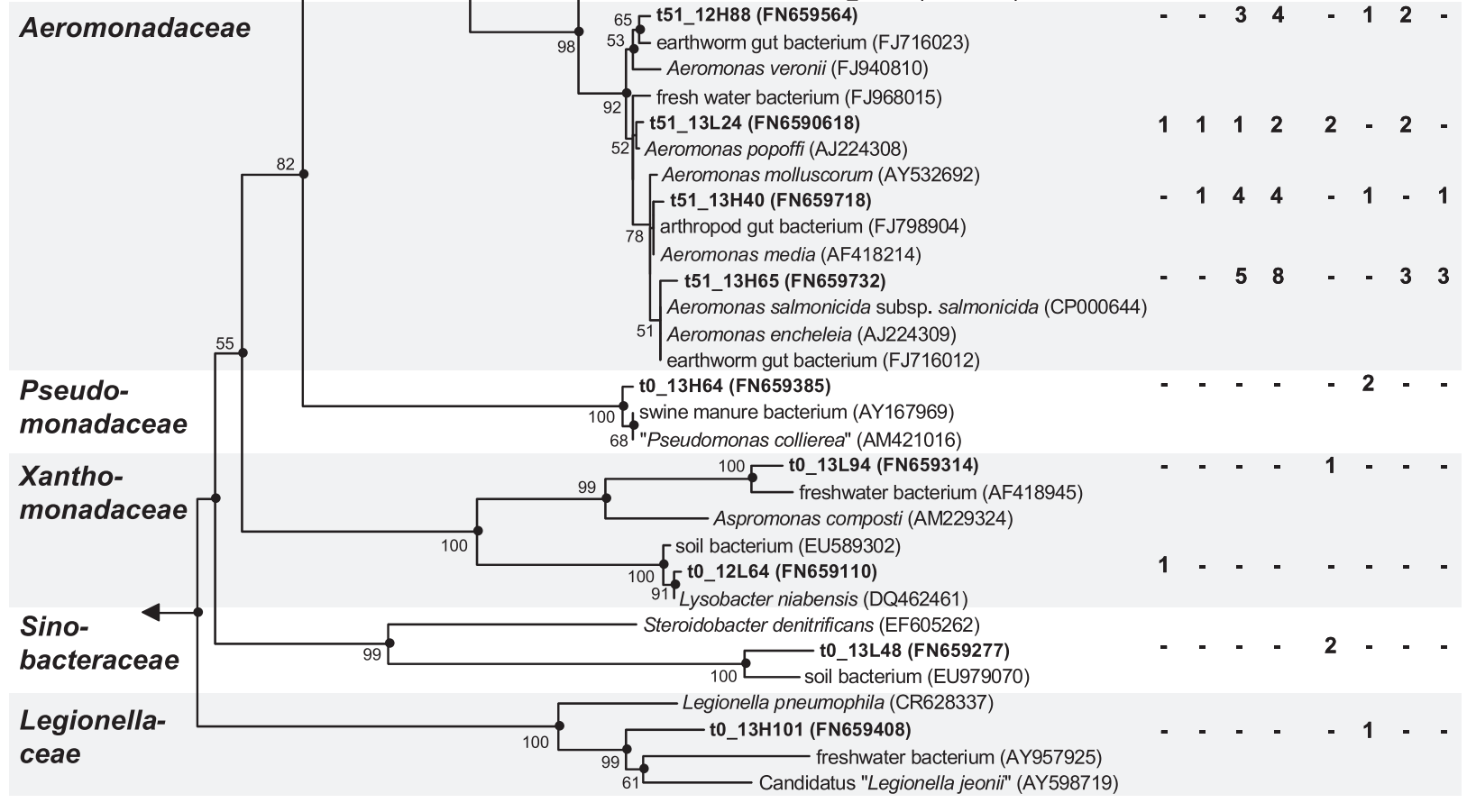

0.05

Figure 4 Continued. 
to ferment glucose (Müller et al., 1996; Ihssen et al., 2003; Brenner and Farmer, 2005; Grimont and Grimont, 2005). Some labeled enterobacterial sequences were affiliated with Buttiauxella agrestis (Figure 4b), strains of which can reduce $\mathrm{N}_{2} \mathrm{O}$ to $\mathrm{N}_{2}$ (Kaldorf et al., 1993). Many labeled enterobacterial sequences were related to $P$. agglomerans (Figure 4b). P. agglomerans produces exoenzymes chitinase, pectinase and protease (Mahmoud et al., 2008), and might therefore contribute to the degradation of complex organic matter in the earthworm gut. The numerous anaerobic capabilities of $P$. agglomerans (Grimont and Grimont, 2005) might confer a selective advantage in $\mathrm{O}_{2}$-limited habitats similar to the earthworm gut. In addition to growing by fermentation, this organism is capable of dissimilating metals such as Fe(III) by using lactate, acetate and $\mathrm{H}_{2}$ as electron donors (Francis et al., 2000). The large amounts of Fe(II) in the earthworm alimentary canal suggest that $\mathrm{Fe}(\mathrm{III})$ reduction occurs in situ and could be driven by such fermentation products (Wüst et al., 2009a).

\section{Limitations and conclusions}

Microcosm experiments do not fully duplicate in situ conditions. Furthermore, a major constraint in interpreting stable isotope probing experiments is the potential labeling that can occur because of cross-feeding (Neufeld et al., 2007). Thus, the limitations of this study should be examined. The 1-10 dilution of gut contents necessitated for obtaining samples for chemical and molecular analyses diluted both taxa and endogenous nutrients, and cross-feeding could have resulted in labeling of taxa that did not directly assimilate glucose. For example, the apparent consumption of small amounts of formate and lactate in unsupplemented microcosms indicated that a limited amount of $\left[{ }^{13} \mathrm{C}\right]$ glucose-derived formate and lactate might have been consumed and thus assimilated. Also, only one of several saccharides potentially available in the gut (Wüst et al., 2009a) was evaluated. The above interpretations must therefore be qualified within the constraints of these limitations. Nevertheless, anoxia, $15^{\circ} \mathrm{C}, 10 \mathrm{mM}$ glucose, neutral $\mathrm{pH}$, and the relatively short incubation period approximated important parameters likely to be of importance to fermentation in the earthworm gut. In addition, if cross-feeding occurred in the microcosms, it could and likely does occur in situ. For example, acetate was a major fermentation product of earthworm gut content (Table 1) and might constitute an in situ trophic link between fermenters and denitrifiers, as it is a substrate for many denitrifiers (Tiedje, 1988). Thus, the labeling observed might theoretically reflect the type of interconnected events that occur during gut passage. However, midgut and hindgut contents contain only marginal amounts of nitrate and nitrite (Wüst et al., 2009a), and no $\mathrm{N}_{2} \mathrm{O}$ was produced in the stable isotope probing microcosms (data not shown), suggesting that cross-feeding of denitrifiers was very unlikely. Indeed, although denitrifying taxa were detected at the beginning of incubation, they were neither labeled nor detected at the end of $51 \mathrm{~h}$ of incubation (Table 2). Although we cannot fully exclude the possibility that cross-feeding occurred, it was likely minimal because of the relatively short incubation period and limited availability of alternative electron acceptors. Furthermore, the majority of ${ }^{13} \mathrm{C}$ from $\left[{ }^{13} \mathrm{C}\right]$ glucose was recovered in fermentation products that accumulated with time, suggesting that subsequent assimilation of these products was minimal. Similarly, selective death and selective predation seem unlikely causes of the marked enrichment of Clostridiaceae and Enterobacteriaceae.

Within these constraints and considerations, the findings of this study suggest that Clostridiaceae and Enterobacteriaceae are subsets of diverse active taxa in the alimentary canal of the earthworm that are capable of consuming mucus- and plant-derived saccharides during gut passage, and illustrate the effect that gut passage might have on selectively stimulating fermentative taxa of ingested soil. Although a minimal cross-feeding might have occurred, the substantial labeling of Clostridiaceae and Enterobacteriaceae indicates that certain ingested obligate anaerobes and facultative aerobes from soil can concomitantly metabolize the same source of carbon. This possibility is consistent with the formation of products considered indicative of clostridial (for example, butyrate) and enterobacterial (for example, succinate) fermentations (Brenner and Farmer, 2005; Rainey et al., 2009) in the midgut and hindgut of the alimentary canal (Wüst et al., 2009a).

\section{Acknowledgements}

We thank Peter Depkat-Jakob for assistance with dissecting worms. Support for this study from the Deutsche Forschungsgemeinschaft (DR310/4-1) and the University of Bayreuth is gratefully acknowledged.

\section{References}

Akila G, Chandra TS. (2003). A novel cold-tolerant Clostridium strain PXYL1 isolated from a psychrophilic cattle manure digester that secretes thermolabile xylanase and cellulase. FEMS Microbiol Lett 219: 63-67.

Bernadet JF, Bowman J. (2006). The genus Flavobacterium. In: Dworkin M, Falkow S, Rosenberg E, Schleifer K-H and Stackebrandt E (eds). The Prokaryotes, 3rd edn. Springer: New York, pp 481-531.

Brenner DJ. (1992). Introduction to the family Enterobacteriaceae. In: Balows A, Trüper HG, Dworkin M, Harder W and Schleifer KH (eds). The Prokaryotes, 2nd edn. Springer Verlag: New York, pp 2673-2695. 
Brenner DJ, Farmer JJ. (2005). Family I. Enterobacteriaceae. In: Brenner DJ, Krieg NR and Staley JT (eds). Bergey's Manual of Systematic Bacteriology, 2nd edn. Springer: New York, pp 587-607.

Broda DM, Lawson PA, Bell RG, Musgrave DR. (1999). Clostridium frigidicarnis sp nov., a psychrotolerant bacterium associated with 'blown pack' spoilage of vacuum-packed meats. Int $J$ Syst Bacteriol 49: 1539-1550.

Broda DM, Saul DJ, Lawson PA, Bell RG, Musgrave DR. (2000). Clostridium gasigenes sp. nov., a psychrophile causing spoilage of vacuum-packed meat. Int J Syst Evol Microbiol 50: 107-118.

Brown GG, Barois I, Lavelle P. (2000). Regulation of soil organic matter dynamics and microbial activity in the drilosphere and the role of interactions with other edaphic functional domains. Eur $J$ Soil Biol 36: 177-198.

Byzov BA, Nechitaylo TY, Bumazhkin BK, Kurakov AV, Golyshin PN, Zvyagintsev DG. (2009). Culturable microorganisms from the earthworm digestive tract. Microbiology 78: 360-368.

Cole JA. (1990). Physiology, biochemistry, and genetics of nitrate dissimilation to ammonia. In: Revsbech NP and Sorensen J (eds). Denitrification in Soils and Sediment. Plenum Press: New York, pp 57-76.

Cole JR, Chai B, Marsh TL, Farris RJ, Wang Q, Kulam SA et al. (2003). The Ribosomal Database Project (RDP-II): previewing a new autoaligner that allows regular updates and the new prokaryotic taxonomy. Nucleic Acids Res 31: 442-443.

Collins MD, Lawson PA, Willems A, Cordoba JJ, FernandezGarayzabal J, Garcia P et al. (1994). The phylogeny of the genus Clostridium: proposal of five new genera and eleven new species combinations. Int J Syst Bacteriol 44: 812-826.

Degelmann DM, Kolb S, Dumont M, Murrell JC, Drake HL. (2009). Enterobacteriaceae facilitate the anaerobic degradation of glucose by a forest soil. FEMS Microbiol Ecol 68: 312-319.

Drake HL. (2010). Lactovum. In: Holzapfel W and Wood BJB (eds). Lactic Acid Bacteria - Biodiversity and Taxonomy. Blackwell Publishing Ltd.: Oxford, (in press).

Drake HL, Gößner AS, Daniel SL. (2008). Old acetogens, new light. In: Wiegel J, Maier RJ and Adams MWW (eds). Incredible Anaerobes: From Physiology to Genomics to Fuels. New York Academy of Sciences: Boston, pp 100-128.

Drake HL, Horn MA. (2007). As the worm turns: the earthworm gut as a transient habitat for soil microbial biomes. Annu Rev Microbiol 61: 169-189.

Drake HL, Küsel K, Matthies C. (2006). Acetogenic prokaryotes. In: Balows A, Trüper HG, Dworkin M, Harder W and Schleifer KH (eds). The Prokaryotes, 3rd edn. Springer: New York, pp 354-420.

Edwards CA, Bohlen PJ. (1996). Biology and Ecology of Earthworms, 3rd edn. Chapman \& Hall: London, 426pp.

Euzéby JP. (2010). List of prokaryotic names with standing nomenclature http://www.bacterio.cict.fr/number.html.

Felsenstein J. (1985). Confidence limits on phylogeniesan approach using the bootstrap. Evolution 39: 783-791.

Fischer K, Hahn D, Honerlage W, Zeyer J. (1997). Effect of passage through the gut of the earthworm Lumbricus terrestris $\mathrm{L}$ on Bacillus megaterium studied by whole cell hybridization. Soil Biol Biochem 29: 1149-1152.

Francis CA, Obraztsova AY, Tebo BM. (2000). Dissimilatory metal reduction by the facultative anaerobe Pantoea agglomerans SP1. Appl Environ Microbiol 66: 543-548.

Furlong MA, Singleton DR, Coleman DC, Whitman WB. (2002). Molecular and culture-based analyses of prokaryotic communities from an agricultural soil and the burrows and casts of the earthworm Lumbricus rubellus. Appl Environ Microbiol 68: 1265-1279.

Good IJ. (1958). The population frequency of species and the estimation of the population parameters. Biometrics 40: 237-246.

Gottschalk G. (1988). Bacterial metabolism 2nd edn. Springer: New York.

Griffiths RI, Whiteley AS, O’Donnell AG, Bailey MJ. (2000). Rapid method for coextraction of DNA and RNA from natural environments for analysis of ribosomal DNA- and rRNA-based microbial community composition. Appl Environ Microbiol 66: 5488-5491.

Grimont PAD, Grimont F. (2005). Genus XXIII. Pantoea. In: Brenner DJ, Krieg NR and Staley JT (eds). Bergey's Manual of Systematic Bacteriology 2nd edn. Springer: New York, pp 713-720.

Hamberger A, Horn MA, Dumont MG, Murrell JC, Drake HL. (2008). Anaerobic consumers of monosaccharides in a moderately acidic fen. Appl Environ Microbiol 74: 3112-3120.

Hammes WP, Hertel C. (2009). Genus I. Lactobacillus. In: De Vos P, Garrity GM, Jones D, Krieg NR, Ludwig W, Rainey FA et al. (eds). Bergey's Manual of Systematic Bacteriology, 2nd edn. Springer: New York, pp 465-511.

Hartenstein F, Hartenstein E, Hartenstein R. (1981). Gut load and transit time in the earthworm Eisenia foetida. Pedobiologia 22: 5-20.

Hartenstein R, Amico L. (1983). Production and carryingcapacity for the earthworm Lumbricus terrestris in culture. Soil Biol Biochem 15: 51-54.

Hedderich R, Whitman WB. (2006). Physiology and biochemistry of the methane-producing Archaea. In: Dworkin MM, Falkow S, Rosenberg E, Schleifer $\mathrm{KH}$ and Stackebrandt E (eds). The Prokaryotes, 3rd edn. Springer: New York, pp 1050-1079.

Horn MA, Ihssen J, Matthies C, Schramm A, Acker G, Drake HL. (2005). Dechloromonas denitrificans sp. nov., Flavobacterium denitrificans sp. nov., Paenibacillus anaericanus sp. nov. and Paenibacillus terrae strain $\mathrm{MH72}, \mathrm{N}_{2} \mathrm{O}$-producing bacteria isolated from the gut of the earthworm Aporrectodea caliginosa. Int $J$ Syst Evol Microbiol 55: 1255-1265.

Horn MA, Schramm A, Drake HL. (2003). The earthworm gut: an ideal habitat for ingested $\mathrm{N}_{2} \mathrm{O}$-producing microorganisms. Appl Environ Microbiol 69: 1662-1669.

Hurlbert SH. (1971). Nonconcept of species diversitycritique and alternative parameters. Ecology 52: 577-586.

Ihssen J, Horn MA, Matthies C, Gößner A, Schramm A, Drake HL. (2003). $\mathrm{N}_{2} \mathrm{O}$-producing microorganisms in the gut of the earthworm Aporrectodea caliginosa are indicative of ingested soil bacteria. Appl Environ Microbiol 69: 1655-1661.

Joseph SJ, Hugenholtz P, Sangwan P, Osborne CA, Janssen PH. (2003). Laboratory cultivation of widespread and previously uncultured soil bacteria. Appl Environ Microbiol 69: 7210-7215. 
Kaldorf M, Linne von Berg KH, Meier U, Servos U, Bothe H. (1993). The reduction of nitrous oxide to dinitrogen by Escherichia coli. Arch Microbiol 160: 432-439.

Karsten GR, Drake HL. (1995). Comparative assessment of the aerobic and anaerobic microfloras of earthworm guts and forest soils. Appl Environ Microbiol 61: 1039-1044.

Karsten GR, Drake HL. (1997). Denitrifying bacteria in the earthworm gastrointestinal tract and in vivo emission of nitrous oxide $\left(\mathrm{N}_{2} \mathrm{O}\right)$ by earthworms. Appl Environ Microbiol 63: 1878-1882.

Knapp BA, Podmirseg SM, Seeber J, Meyer E, Insam H. (2009). Diet-related composition of the gut microbiota of Lumbricus rubellus as revealed by a molecular fingerprinting technique and cloning. Soil Biol Biochem 41: 2299-2307.

Küsel K, Drake HL. (1995). Effects of environmental parameters on the formation and turnover of acetate by forest soils. Appl Environ Microbiol 61: 3667-3675.

Lane DJ. (1991). 16S/23S rRNA sequencing. In: Stackebrandt E and Goodfellow M (eds). Nucleic acid techniques in bacterial systematics. John Wiley \& Sons Ltd.: Chichester, England, pp 205-248.

Lavelle P, Bignell D, Lepage M, Wolters V, Roger P, Ineson $\mathrm{P}$ et al. (1997). Soil function in a changing world: the role of invertebrate ecosystem engineers. Eur J Soil Biol 33: 159-193.

Lee KE. (1985). Earthworms. Their Ecology and Relationships with Soils and Land Use. Academic Press: Sydney, 411pp.

Liu Y, Whitman WB. (2008). Metabolic, phylogenetic, and ecological diversity of the methanogenic Archaea. In: Wiegel J, Maier RJ and Adams MWW (eds). Incredible Anaerobes: From Physiology to Genomics to Fuels pp 171-189.

Lüders T, Manefield M, Friedrich MW. (2004). Enhanced sensitivity of DNA- and rRNA-based stable isotope probing by fractionation and quantitative analysis of isopycnic centrifugation gradients. Environ Microbiol 6: 73-78.

Ludwig W, Schleifer KH, Whitman WB. (2009). Revised road map to the phylum Firmicutes. In: De Vos P, Garrity GM, Jones D, Krieg NR, Ludwig W, Rainey FA et al. (eds). Bergey's Manual of Systematic Bacteriology, 2nd edn. Springer: New York, pp 1-15.

Ludwig W, Strunk O, Westram R, Richter L, Meier H, Yadhukumar et al. (2004). ARB: a software environment for sequence data. Nucleic Acids Res 32: 1363-1371.

Macfarlane S, Macfarlane GT. (2003). Regulation of short-chain fatty acid production. Proc Nutr Soc 62: $67-72$.

Mahmoud DAR, Mahmoud AA, Gomaa AM. (2008). Antagonistic activities of potato associated bacteria via their production of hydrolytic enzymes with special reference to pectinases. Res J Agric Biol Sci 4: $575-584$.

Makeschin F. (1997). Earthworms (Lumbricidae: Oligochaeta): important promoters of soil development and soil fertility. In: Benckiser G (ed). Fauna in soil ecosystems. Marcel Dekker Inc.: New York. pp 173-223.

Martin-Carnahan A, Joseph SW. (2005). Genus I. Aeromonas. In: Brenner DJ, Krieg NR, Staley JT (eds). Bergey's Manual of Systematic Bacteriology, 2nd edn. Springer: New York, pp 557-578.

Martin A, Cortez J, Barois I, Lavelle P. (1987). The production of intestinal mucus by earthworms- a key process in their interactions with the soil microflora. Rev Ecol Biol Sol 24: 549-558.

Matthies C, Gossner A, Acker G, Schramm A, Drake HL. (2004). Lactovum miscens gen. nov., sp. nov., an aerotolerant, psychrotolerant, mixed-fermentative anaerobe from acidic forest soil. Res Microbiol 155: 847-854.

Matthies C, Griesshammer A, Schmittroth M, Drake HL. (1999). Evidence for involvement of gut-associated denitrifying bacteria in emission of nitrous oxide $\left(\mathrm{N}_{2} \mathrm{O}\right)$ by earthworms obtained from garden and forest soils. Appl Environ Microbiol 65: 3599-3604.

McInerney MJ, Struchtemeyer CG, Sieber J, Mouttaki H, Stams AJM, Schink B et al. (2008). Physiology, ecology, phylogeny, and genomics of microorganisms capable of syntrophic metabolism. In: Wiegel J, Maier RJ and Adams MWW (eds). Incredible Anaerobes: From Physiology to Genomics to Fuels. New York Academy of Sciences: Boston, pp 58-72.

Messing J. (1983). New M13 vectors for cloning. Meth Enzymol 101: 20-78.

Müller HE, Brenner DJ, Fanning GR, Grimont PA, Kämpfer P. (1996). Emended description of Buttiauxella agrestis with recognition of six new species of Buttiauxella and two new species of Kluyvera: Buttiauxella ferragutiae sp. nov., Buttiauxella gaviniae sp. nov., Buttiauxella brennerae sp. nov., Buttiauxella izardii sp. nov., Buttiauxella noackiae sp. nov., Buttiauxella warmboldiae sp. nov., Kluyvera cochleae sp. nov., and Kluyvera georgiana sp. nov. Int J Syst Bacteriol 46: 50-63.

Nanninga HJ, Gottschal JC. (1985). Amino acid fermentation and hydrogen transfer in mixed cultures. FEMS Microbiol Ecol 31: 261-269.

Neufeld JD, Dumont MG, Vohra J, Murrell JC. (2007). Methodological considerations for the use of stable isotope probing in microbial ecology. Microb Ecol 53: 435-442.

Priest FG. (2009). Genus I. Paenibacillus. In: De Vos P, Garrity GM, Jones D, Krieg NR, Ludwig W, Rainey FA et al. (eds). Bergey's Manual of Systematic Bacteriology, 2nd edn. Springer: New York, pp 269-295.

Pruesse E, Quast C, Knittel K, Fuchs BM, Ludwig WG, Peplies J et al. (2007). SILVA: a comprehensive online resource for quality checked and aligned ribosomal RNA sequence data compatible with ARB. Nucleic Acids Res 35: 7188-7196.

Rahemtulla F, Lovtrup S. (1975). Comparative biochemistry of invertebrate mucopolysaccharides .3. Oligochaeta and Hirudinea. Comp Biochem Physiol B, Biochem Mol Biol 50: 627-629.

Rainey FA, Hollen BJ, Small A. (2009). Genus I. Clostridium. In: De Vos P, Garrity GM, Jones D, Krieg NR, Ludwig W, Rainey FA et al (eds). Bergey's Manual of Systematic Bacteriology, 2nd edn. Springer: New York.

Reid SJ. (2005). Genetic organization and regulation of hexose and pentose utilization in the Clostridia. In: Dürre P (ed). Handbook on Clostridia. CRC Press: Boca Raton, pp 133-153.

Saitou N, Nei M. (1987). The neighbor-joining methoda new method for reconstructing phylogenetic trees. Mol Biol Evol 4: 406-425.

Schellenberger S, Kolb S, Drake HL. (2010). Metabolic responses of novel cellulolytic and saccharolytic agricultural soil Bacteria to oxygen. Environ Microbiol 12: $845-861$. 
Schloss PD, Larget BR, Handelsman J. (2004). Integration of microbial ecology and statistics: a test to compare gene libraries. Appl Environ Microbiol 70: 5485-5492.

Singleton DR, Hendrix PF, Coleman DC, Whitman WB. (2003). Identification of uncultured bacteria tightly associated with the intestine of the earthworm Lumbricus rubellus (Lumbricidae; Oligochaeta). Soil Biol Biochem 35: 1547-1555.

Tamura K, Dudley J, Nei M, Kumar S. (2007). MEGA4: molecular evolutionary genetics analysis (MEGA) software version 4.0. Mol Biol Evol 24: 1596-1599.

Teuber M, Geis A, Neve H. (1992). The genus Lactococcus. In: Balows A, Trüper HG, Dworkin MM, Harder W and Schleifer KH (eds). The Prokaryotes, 2nd edn. Springer: New York, pp 1482-1501.

Tiedje JM. (1988). Ecology of denitrification and dissimilatory nitrate reduction to ammonium. In: Zehnder AJB (ed). Biology of Anaerobic Microorganisms. John Wiley and Sons: New York, pp 179-243.

Trigo D, Barois I, Garvin MH, Huerta E, Irisson S, Lavelle P. (1999). Mutualism between earthworms and soil microflora. Pedobiologia 43: 866-873.

Umarov MM. (1990). Biotic sources of nitrous oxide in the context of the global budget of nitrous oxide. In: Bouwman AF (ed). Soils and the Greenhouse Effect. John Wiley and Sons: Chichester, pp 263-268.

Wang Q, Garrity GM, Tiedje JM, Cole JR. (2007). Naive Bayesian classifier for rapid assignment of rRNA sequences into the new bacterial taxonomy. Appl Environ Microbiol 73: 5261-5267.

Whiley RA, Hardie JM. (2009). Genus I. Streptococcus. In: De Vos P, Garrity GM, Jones D, Krieg NR, Ludwig W, Rainey FA et al (eds). Bergey's Manual of Systematic Bacteriology, 2nd edn. Springer: New York, pp 655-711.

Wiegel J, Tanner R, Rainey FA. (2006). An introduction to the family Clostridiaceae. In: Balows A, Trüper HG, Dworkin M, Harder W and Schleifer KH (eds). The Prokaryotes. Springer: New York, pp 654-678.

Wüst PK, Horn MA, Drake HL. (2009a). In situ hydrogen and nitrous oxide as indicators of concomitant fermentation and denitrification in the alimentary canal of the earthworm Lumbricus terrestris. Appl Environ Microbiol 75: 1852-1859.

Wüst PK, Horn MA, Henderson G, Janssen PH, Rehm BHA, Drake HL. (2009b). Gut-associated denitrification and in vivo emission of nitrous oxide by the earthworm families Megascolecidae and Lumbricidae in New Zealand. Appl Environ Microbiol 75: 3430-3436.

Yarza P, Richter M, Peplies J, Euzéby J, Amann R, Schleifer $\mathrm{KH}$ et al (2008). The All-Species Living Tree project: a 16S rRNA-based phylogenetic tree of all sequenced type strains. Syst Appl Microbiol 31: 241-250.

Zhang Z, Schwartz S, Wagner L, Miller W. (2000). A greedy algorithm for aligning DNA sequences. J Comput Biol 7: 203-214. 